\title{
LEATHER PROCESSING, ITS EFFECTS ON ENVIRONMENT AND ALTERNATIVES OF CHROME TANNING
}

\author{
Karanam Sai Bhavya, Raji P, Jenifer Selvarani A \\ Department of Biotechnology, School of Bio and Chemical Engineering, \\ Sathyabama Institute of Science and Technology, Jeppiaar Nagar, Chennai, Tamil Nadu, India \\ Antony V Samrot*, Pazhayakath Thevarkattil Mohamed Javad \\ Department of Biomedical Sciences, Faculty of Medicine and Biomedical Sciences, MAHSA \\ University, Jenjarom, Selangor 42610, Malaysia
}

\begin{abstract}
Appalaraju, V.V.S.S
Department of Medicinal Chemistry, Faculty of Pharmacy, MAHSA University, Jalan SP2, Bandar Saujana Putra, 42610 Jenjarom, Selangor, Malaysia.

*Corresponding Author Email id: antonysamrot@gmail.com
\end{abstract}

\begin{abstract}
There are several processes involved in leather making, one of the process is tanning. In tanning process, higher concentration of chromium is commonly used. Whereas chromium is regarded as one of the toxic heavy metal. The disposal of these chromium effluent into water bodies is known to cause various ill effects. To replace that, vegetable tanning can be practiced, where the method is easy as well as ecofriendly. In this review, we have dealt about various procedures in leather processing especially chrome tanning and health hazards caused by chromium. Also added a note on vegetable tanning using tannins to replace the chrome tanning for making better environment.
\end{abstract}

Keywords: Tanning; chromium; tannins.

Cite this Article: Karanam Sai Bhavya, Raji P, Jenifer Selvarani A, Antony V Samrot, Pazhayakath Thevarkattil Mohamed Javad, Appalaraju, V.V.S.S, Leather Processing, Its Effects on Environment and Alternatives of Chrome Tanning, International Journal of Advanced Research in Engineering and Technology (IJARET), 10 (6), 2019, pp 69-79.

$\mathrm{http}: / /$ iaeme.com/Home/issue/IJARET?Volume $=10 \&$ Issue $=6$

\section{INTRODUCTION}

Processing of skin or hides into stable material - leather is known as tanning. Leather, the primary product from the tanning industry, where the product has got its applications in making footwear, furniture, bags, etc., [1,2]. The global leather industry generated about 18 
billion square feet leather in 2003 with an estimated price of US $\$ 40$ billion (World Leather Magazine). Most developing countries including India is producing $60 \%$ of world's leather needs. For making the leather, Tanning is considered as a major process which involves more chemical reactions as well as mechanical operations. During the process more chemicals including chromium, acid solvents, etc are involved, these processes release effluent of $30 \mathrm{~L} / \mathrm{kg}$ of processed skin [3], where tanneries of India are releasing effluent more than 50,000 $\mathrm{mg}$ /day with huge quantity of organic pollutants [4]. $70 \%$ of chrome (III) is usually discharged (IULTCS, 2008) and leads to heavy metal contamination in water $[5,6]$. Release of chromium by tanneries are higher now than mentioned parameters.

Chromium, a major heavy metal exploited in leather industry. In India, it was found to release 30 billion of waste water with $3000-5000 \mathrm{mg} / \mathrm{L}$ of total solids and chromium in between $100-200 \mathrm{mg} / \mathrm{L}$ on processing 700,000 tons of skins in about 3000 tanneries [7]. More than 170,000 tons of with $0.04 \mathrm{Mt} \mathrm{Cr}$ (III) wastes per year are released into environment worldwide [3, 6]. With the enhancement of environment realization and change in manufacture patterns, the world industry is desirous to take cleaner and greener approaches for leather processing [8].

The global leather have been in existence during which technologists were concerned to inflict stability to raw skins and hides [9]. Until the approach of chrome tanning, there were very few options available for tanners such as aluminium tawing, smoke tanning, oil tanning and vegetable tanning. The term tannin was firstly used in 1796 by Seguin in order to specify the specific components of vegetable extracts having a potential to bind with collagen making insoluble complexes by blocking the action of other proteolytic enzymes which effect the physical condition of the skin [10]. The process of this extraction may include non-tannins and other materials which have no tanning strength which contributes in determining the functional properties of the leather. Oils of animals Leather are also smoke tanning where the oil in animal's brain used as tanning agent which gives highly durable leather [11]. Today chrome tanning is the most commonly used method which accounts for world's leather producton [12]. Although chrome tanning has many advantages like high speed, low cost, good hide storage, etc $40 \%$ of the chromium remains in the effluent which end up in sludge [13]. One of the major problem of leather industry is chromium disposal where the treatment results in chromium contaminated sludge [14]. Due to these disadvantages of chrome tanning tanners are encouraged to use the ecofriendly process of tanning like vegetable tanning.

\section{HISTORY OF TANNING}

Tanning is one of the ancient trades of humanity in reference to use of leathers in archeological sites and cave paintings. Tanning had a random nature which has evolved slowly into craft in the middle age. The scientific studies on tanning started in nineteenth century and derived into present day leather technology with the development of machinery and industrial revolution. The Egyptians made long-lasting leather which is 3000 years old specimen but still in good condition which made the evidence for oil tanning [10]. The Rudimental processing of leather is mentioned in Assyrian texts and in Homer's Iliad [15]. At first the skins obtained from hunting and livestock breeding were used for clothing and tents but they became stiff at low temperatures and rotted with heat which was overcome after many attempts by a process called smoking where the animal fats were rubbed for getting more render and flexible and this process became an origin for leather processing by accident [16]. From middle ages till $17^{\text {th }}$ century there was no change in skin processing. At the end of $18^{\text {th }}$ century with the development of industrialisation created a demand for different types of leathers for belting in machines, leathers for textiles, footwear, fabrics, etc. Similarly, at the end of $19^{\text {th }}$ century the tanning industry was developed with the discovery of various 
chemicals as tanning agents and finally with the discovery of major tanning agents like chromium and alum pointed the beginning of industrial scale tanning. According to references, it is Neolithic period where man started using plant materials such as bark, pods, leaves to prevent skins from putrefaction forming the most stable and durable material [1720]. The term skin is the one used to determine the outer part of mature animals of smaller type such as Pigs, goats, reptiles, fish, etc whereas the term hide is referred as the outer part of large animals such as buffalo and cattle [21].

\section{STEPS INVOLVED IN LEATHER PROCESSING}

\subsection{Soaking}

Soaking is the first step involved in tanning where the preserved raw skins or salted skins are treated with water to make the skin dirt free and soft [22]. The main purpose of soaking is to remove salt, rehydrate the dry skin and also to remove unwanted materials like blood, soil, dung, etc. The soaking time depends on condition of skins or hides [23].

\subsection{Liming}

The second operation is liming which involves the removal of hair and unwanted materials which are not transferred to leather. It also loosens the epidermis and also remove soluble skin proteins. It uses lime and sodium sulphide as liquor [24]. The hair is loosened due to increase in high $\mathrm{pH}$. The higher $\mathrm{pH}$ also cause splitting and swelling of fibre bundles [25]. Dehairing and fleshing is also done in order to remove extra flesh and allow tannins to penetrate easily.

\subsection{Deliming}

Deliming is the process of adjusting $\mathrm{pH}$ between 8-9 which enhances the enzyme activity and converts proteins into soluble forms. It uses ammonium sulphate and results in de-swelling of pelts [26]. Deliming decreases the plumping of skin or hide.

\subsection{Bating}

Bating makes the grain surface soft and flexible. It prepares skin for tanning. It is an enzymatic operation which removes unwanted proteins and increases the degree of stretch [27]. It imparts flexibility and softness towards the leather.

\subsection{Degreasing}

Degreasing is a process used to remove extra fat and oils which allows the tannin to penetrate easily through the skin. This step can be carried out by emulsion of fats using detergents or surfactants

\subsection{Tanning}

Tanning is the main operation which converts skin or hide to stable material called leather. In this step tannins are allowed to interact with the prepared skin which act on collagen and make it stable.

\subsection{Fixing}

Formic acid is mostly used in this process which ensures homogenous tanning of hides in leather processing [28]. 
Karanam Sai Bhavya, Raji P, Jenifer Selvarani A, Antony V Samrot,

Pazhayakath Thevarkattil Mohamed Javad, Appalaraju, V.V.S.S

\section{TYPES OF TANNING}

\subsection{Mineral Tanning}

Mineral tanning is a process which uses basic chromium sulphate as tanning agent after the process of pickling. Once the desired level of penetration the $\mathrm{pH}$ is again increased to facilitate the process which is termed as basification and the obtained product is called as wet blue [28].

\subsection{Tawing}

Tawing is another practice which uses aluminum salts and alum along with other materials such as flour, egg yolk and other salts. It is an age old traditional process which gives a wet white product. In this method the skin is tawed in alum and salt solution which increases flexibility, stretchability, etc whereas egg yolk and flour enhances the handling properties [20]. Tawing was conventionally used on goatskins and pigskins [28].

\subsection{Chrome Tanning}

Chrome tanning is the most commonly used tanning process. It uses Chromium (III) sulfate which has been considered as the most effective and efficient tanning agent [29, 30]. It forms poly chromium compounds by a process called olation which acts as active compounds in tanning that crosslinks the collagen subunits [31]. The leather obtained by chromium contain 4-5\% of chromium [32] and its efficiency is determined by enhanced hydrothermal stability and resistance to shrinkage at high temperature. Although chrome is an effective tanning agent it is having some hazards towards human.

\section{EFFECTS OF CHROME TANNING TOWARDS HUMAN}

Chromium in its +6 oxidation state is referred to as Hexavalent chromium. It is mainly used for coatings, wood preservation, dyeing, etc [28]. The chromate mimics the sulphate in its structure and surface charge which can enter the cell and cause cancer, eye irritation and skin allergies. There is a high risk of getting cancers to the workers exposed to hexavalent chromium for a prolonged time. It has been reported lung cancer among workers in chromium chemical production [33]. Repeated exposure to hexavalent can also damage the respiratory tract and may also cause nasal cancer [34]. Direct eye contact of chromate cause permanent eye damage and eye irritation [35]. Prolonged exposure to skin cause skin allergies, dryness, fissured skin, skin ulcers and swelling [36]. In other way some workers may develop allergic sensitization where exposure to small amount cause serious skin rash. Other effects of chromium include dizziness, growth problems, reproductive disorders, discoloration and erosion of teeth $[34,35]$.

\section{VEGETABLE TANNING}

Vegetable tanning is the most suitable ecofriendly process which results in release of less pollutants to the environment [37]. Vegetable tanning involves usage of tannins extracted from various parts of a plant. It mainly depends on amount of tannins in the extract which can be determined by various methods such as Folins Denis method, Mass spectrophotometer, UV detection, Reverse-phase High pressure liquid chromatography (HPLC), Mass spectrophotometer, nuclear magnetic resonance and Circular dichroism [38,39]. Vegetable tanning is a two stage tanning which includes fixing and penetration. Penetration involves diffusion of tannins into the skin whereas fixing makes the penetrated tannins bind with collagen forming stable material. It is mainly affected by several factors such as temperature, $\mathrm{pH}$, mechanical actions and particle size $[40,41]$. The $\mathrm{pH}$ is the most important factor that 
affects the penetration and fixing of tannins. The reduction of $\mathrm{pH}$ in tanning liquor increases the potential of collagen fibres to swell and increasing the tendency of tannins to bind with collagen [42]. Temperature is another most important parameter which affects the vegetable tanning. Increase in temperature results in high diffusion of tannins and gives high degree of tannage [43]. Acid and salt content in tannin liquor greatly influences the physical condition of leather [42]. Control of these parameters results in production of most stable and flexible leather which results in release of less contaminants and thereby protecting the environment. Hence the current study is an eco-friendly approach which reduces the toxic waste generation when compared to chrome tanning process and thereby reducing environmental impacts by contributing towards greener or cleaner development of leather processing

\subsection{Types of Tannins}

Tannins are water soluble phenolic compounds that are capable of animal skins or hides to leather [44]. They are mainly grouped into two types, condensable and hydrolysable tannins based on their structural properties.

\subsubsection{Hydrolysable Tannins}

Hydrolyzable tannins have a molecular weight of 500-3000Da and it has a gallic acid esterified with glucose [45]. These tannins are found only in dicotyledonous plants. They are subgrouped in to gallotannins and ellagitannins [46]. These tannins have D-Glucose at the centre where hydroxyl groups of carbohydrates are partially or completely esterified with phenolic group's i.e ellagic acid in case of ellagitannins and gallic acid in case of gallotannins [47].

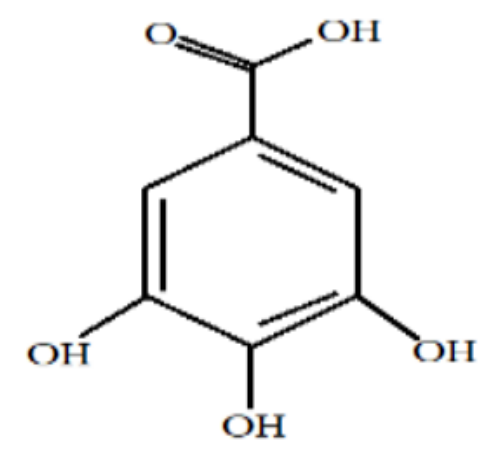

Figure 1 Structure of hydrolysable tannins

Gallotannins are the polymers of galloyl units that are bound to many polyol units which are derived from D-Glucose where the hydroxyl functions of polyol may be substituted by galloyl units [44]. Ellagitannins contains galloyl units along with hexahydroxydiphenol units (HHDP) which is formed by oxidation of galloyl groups [48, 44].

\subsubsection{Condensed Tannins}

Condensed tannins are non-branched polymer of flavanoids having a high molecular weight of 1000-20,000 $\mathrm{Da}$ [49]. The monomers of condensable tannins include catechin and epicatechin [45]. Condensable tannins are the most common tannin found in almost all families of plants [45]. 


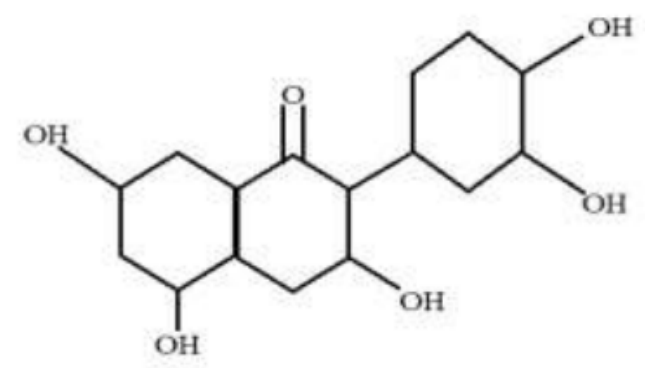

Figure 2 Structure of condensed tannins

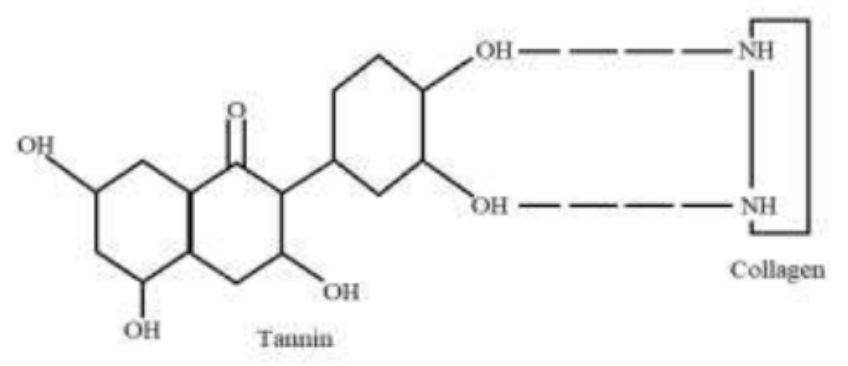

Figure 3 Mechanism of tanning

\subsection{Vegetable Tanning and the Mechanism of Tanning}

Vegetable tanning refers to tanning of skins or hides using the tannins obtained from barks and leaves [50]. Tannins are astringent, water soluble polyphenolic compounds with a molecular weight of 500-20,000and have an ability to precipitate proteins [49]. Tannins can be found in different parts of plant like fruit, seed, pod, stem, leaves, tuber, etc [50]. There are mainly two types of tannins based on their properties and structure. Both hydrolysable and condensed tannins are used in tanning process. The quality of leather differs based on the source of tanning materials. The tanning materials also affects the physical characteristics of leather which are taken from same origin [51]. Vegetable tanned leathers were found to have high wear resistance, molding properties, solidness and flexible endurance [52, 53]. Vegetable tanned leather is highly used in making shoe upper leather, furniture leather and garment leather.

The mechanism of vegetable tanning involves interaction of basic group's collagen protein with the acidic group of tannins by polyfunctional cross-linking [54]. The interaction between protein and tannin is mainly hydrophobic and hydrogen bonding as shown in Fig. 2.3. They form hydrogen bonding between peptide oxygen of collagen and polyphenolic $-\mathrm{OH}$ groups or between oxygen atoms of phenolic -OH groups and protonated amino groups [55, $56,32]$. The factors that are mainly responsible for tanning mechanism are $\mathrm{pH}$, temperature, tannin concentration, salt content and condition of hide [54].

\subsection{Commonly Used Vegetable Tannins}

Various vegetable tanning materials are used in leather processing all over the world based on tannin concentration and also their availability in plants. Some of the plants used for tanning are quebracho (20\%), chest nut (10.7\%), behra nuts, etc [57]. Most of the acacia species are used for tanning due to the presence of high tannin concentration [57, 58]. 


\section{NANOTECHNOLOGY IN LEATHER PROCESSING}

Nanoparticles,because of their small size and their ability to combine with polymers shows its potential for the application in tanning [59]. Introduction of nanoparticles into tanning agents enhances the physical and mechanical properties of leather [60]. In order to this, silver nanoparticles due to its properties against bio-activities they can even impart some functional properties such as anti-microbial, UV-resistance and fungal resistance of leather [60-63]. Raji et al (2019) used various tannins mediated silver nanoparticles for tanning process and able to produce a stable leather [64].

\section{LEATHER AND ENVIRONMENT}

Global environment is continuously deteriorating due to many socio-economic activities of human [65]. Processing industries are causing much damage to the environment. Leather processing is one such industry which takes skins from meat industry and processed to produce leather through tanning process [66]. It gained negative impact in society because of its pollution. Leather processing involves various operations which include many chemicals that are expelled out in processing [67]. 40 litres of water is required for processing $1 \mathrm{~kg}$ of skin which results in generation of large amount of effluent leading to increase in Biological oxygen demand, Chemical oxygen demand, Dissolved oxygen, etc $[5,68,69]$. It also results in emission of chromium and sulfate ions [70]. Leather industry also emits obnoxious smell due to protein degradation of the skin and results in generation of toxic gases such as ammonia, $\mathrm{H}_{2} \mathrm{~S}$,etc [71]. According to the research data only $20 \%$ of the raw hide is used for production of leather where the remaining is generated as waste [72]. Hence leather industry is considered as one of the major polluting industries which generates huge amount of solid and liquid wastes. The most important approach for prevention of environmental pollution is getting an idea prevention is better than reuse which is better than disposal of wastes [72]. There are various recycling methods to make generated leather wastes into eco-friendly useful bi-products such as production of fatliquoring oils and bio-diesel from pre-fleshing wastes [27,73], production of activated carbon [74,75], gelatin, retanning agents [76,77] etc., from shavings and trimmings, production of grease, methane gas, fertilizers, etc., [78,79] from fleshing waste. Hence cleaner production and recycling are the best options in order to control environmental pollution.

\section{REFERENCES}

[1] A.S. Lawal, and C.P. Odums, Tanning of Different Animal Skins/Hides and Study of Their Properties for Textile Application. British Journal of Applied Science \& Technology, 5(6), $2015,588$.

[2] Y. Li, Z.H. Shan, S.X. Shao, K.Q. Shi. Mechanism of chrome-free tanning withtetrahydroxymethyl phosphonium chloride. J. Soc. Leather Tech. Chem. 5, 2006, pp 214-216.

[3] M. Doble, and A.K. Kruthiventi, Industrial Examples. Green Chemistry and Engineering, 2007, 245-296. doi:10.1016/b978-012372532-5/50010-9

[4] V. Tare, S. Gupta, and P. Bose, Case Studies on Biological Treatment of Tannery Effluents in India, Journal of the Air \& Waste Management Association, 53(8), 2003, pp 976-982.

[5] P. Thanikaivelan, J.R. Rao, B.U. Nair, and T. Ramasami, Underlying principles in chrome tanning: Part II. Underpinning mechanism in pickle-less tanning J. Am. Leather Chem. As, 99, 2004, pp 83-93.

[6] J.M. Morera, Bartoli, R. Chico, C. Sole, and L.F. Cabeza. Minimization of the environmental impact of chrome tanning: a new process reusing the tanning floats. Journal of Cleaner Production, 19(17), 2011, pp 2128-213. 
Karanam Sai Bhavya, Raji P, Jenifer Selvarani A, Antony V Samrot,

Pazhayakath Thevarkattil Mohamed Javad, Appalaraju, V.V.S.S

[7] S. Rajamani, T. Ramasami, J.S.A Langerwerf, J.E. Schappman, Environmental Management in Tanneries-Feasible Chromium Recovery and Reuse System. In Proceedings of the 3rd International Conference on Appropriate Waste Management Technologies for Developing Countries, Nagpur, India, 1995, 965.

[8] G. Krishnamoorthy, S. Sadulla, P.K. Sehgal, A.B. Mandal, Greener approach to leather tanning process: d-Lysine aldehyde as novel tanning agent for chrome-free tanning. Journal of cleaner production, 42, 2013, pp 277-286.

[9] A.D. Covington, Tanning chemistry: the science of leather, The Royal Society of Chemistry, Cambridge, 10, 2009, pp 95-105.

[10] D. Seigler, Integrative Biology, plant and their uses, USA. 217, 2005, pp 333-7577.

[11] J. Boren, T. Terrel, J. Brian, Hurd, and G. Mason, Tanning deer hides and small fur skins, Guide L-103, 2009.

[12] D. Tegtmeger, and M. Kleban, Chrome and leather research, a balanced view of scientific facts and figures. International Union of Leather Technologist and Chemist Societies, 2013.

[13] M. Mwinyihija, J. Strachan, J. Dawson, A. Mehang, and K. Kilham, An eco-toxicological Approach to assessing the impacts of tanning industries effluent on river health. Arch Environs Contam Toxicol 50, 2006, pp 316-324.

[14] M. Moorthy, V. Selvi, D. Mekonnen and S. Habtamu, Preparation of Eco-friendly leather by process modification to make pollution free tanneries. Journal of Engineering, Computer and Applied Science, 2(5), 2013, pp 17-22.

[15] R. Reeds, Science for students of leather technology. 4th Edition. 1996, pp 234-556.

[16] J.H. Sharphouse, Theory and practice ofmodern chamois leather production. J.Soc. Leather Technol. Chem. 69, 1985, pp 29-43.

[17] R.J. Forbes, Studies in Acient Technology, Brill Archive, 2, 1966.

[18] E. Haslam, Vegetable tannage: where do all the tannins go?, Journal of the Society of Leather Technologists and Chemists, 81(2), 1997, pp 45-51.

[19] Z. Goffer, Archaeological Chemistry, 2nd ed.; John Wiley \& Sons: Hoboken, NJ, USA, 2007, ISBN 978-0-471-25288-7.

[20] R. Reed, Ancient Skins, Parchments and Leathers; Seminar Press: London, UK; New York, NY, USA, 1972, ISBN 978-0-129-03550-3.

[21] Mwinyihija, Hides, Skins and Leather value addition initiative, the Kenyan scenario, held at Nairobi Safari Club, Mawingu Conference Room, on 23rd -25 2010.

[22] K. Marion, and T. Roy, Conservation of leather and related materials. ButterworthHeinemann. 2006, Pg 33, ISBN 978-0-7506-4881-3

[23] B.M. Yapici, A.N. Yapici, and E.C. Kecici, The effect of reuse of unhairing-liming residual floats through regeneration on the microorganism number. African Journal of Biotechnology. 7, 2008, pp 3077-3081.

[24] F.R. Souza, and M. Gutterres, Application of enzyme in leather processing: A comparison between chemical and coenzyme processes. Brazilian Journal of Chemical Engineering, 29(3), 2012, pp 473-481.

[25] K.T. Sarkar, Theory and practice of leather manufacturer 4th Edition, Revised publisher, 1995, pp 201-224.

[26] R. Gunter, SLTC, Society of Leather Technologist and Chemists Pocket book. SLTC publisher, East Yorkshire, UK, 1999, pp 72-73. 
[27] L.M. Santos, and M. Gutterres, Reusing of a hide waste for leather fat liquoring. Journal of Cleaner Production, 15, 2006, pp 12-16.

[28] M. Sathiyamoorthy, V. Selvi, D. Mekonnen, S. Habtamu, Preparation of eco-friendly leather by process modifications to make pollution free tanneries. Journal of Engineering, Computers \& Applied Sciences (JEC\&AS), 2, 2013, pp 17-22.

[29] J.A. Wilson, the Chemistry of Leather Manufacture. The Chemical Catalog Company, Inc. New York 1923.

[30] A. Covington, Modern Tanning Chemistry, Chemical Society Review, 26, 1997, 111126. doi:10.1039/CS9972600111

[31] J.W. Harlan, S.H. Feairheller, Chemistry of the crosslinking of collagen during tanning. Adv. Exp. Med. Biol. 1977, 86A, pp 425-440.

[32] K.H. Gustavson, the Chemistry of Tanning Processes, Academic Press Inc., New York, 1956.

[33] H.J. Gibb, P.S. Lees, P.F. Pinsky, and B.C. Rooney, Lung cancer among workers in chromium chemical production American Journal of Industrial Medicine (AJIM) 38(2), 2002, pp 115126.

[34] N. Graham, Guidelines for Drinking-Water Quality, Addendum to Volume 1Recommendations, World Health Organisation, Geneva, 1998, pp 1-36.

[35] T.A. Risco, Budiawan, E.I. Auerkari, Effects of Chromium on Human Body. Annual Research \& Review in Biology. 13, 2017, 1-8. 10.9734/ARRB/2017/33462.

[36] X.H. Zhang, X. Zhang, X.C. Wang, L.F. Jin, Z.P. Yang, C.X. Jiang, Q. Chen, X.B. Ren, J.Z. Cao, Q. Wang, and Y.M. Zhu, Chronic occupational exposure to hexavalent chromium causes DNA damage in electroplating workers. BMC Public Health, 11(1), 2011, pp 224.

[37] M.A. Jianzhong, L. Yun, L. Bin, G. Dangge, and W. Likun, Synthesis and properties of tannin/ vinyl polymer tanning agents, 2009.

[38] I. Gu, M.A. Kelm, J.F. Hammerstone, Z. Zhang, G. Beecher, J. Holden, D. Haytowitz and R.L. Prior. Liquid chromatographic/ electrol spray ionization mass spectrometric studies of proanthocyanins in foods. Journal of Mass Spectrum, 38(12), 2003, pp 1272-1280.

[39] M. Saltmarsh, C.S. Buelga and G. Williamson, Methods in polyphenols analysis, The Royal Society of Chemist publisher, 2003, pp 1-5.

[40] A.E. Hergerman, C.T. Robbins, X.J. Weeradurigas, T.C. Wilson, and M.C. Arthur, Tannins chemistry in relation to digestion. Journal of Range Management.45, 1992, pp 4-50.

[41] C. Ogiwara, Practical guide to leather processing, Tokyo Japan Ferozsons printers Ltd., 1980, pp 103-123.

[42] R. Reed, Science for students of leather technology, pergamon press, 2013, 30-240.

[43] T. Thorstensen, Practical leather technology. 4th edition, Krieger publisher company Malabar, Florida: ISBN 0-89464-689-3, 1993, pp 147-171.

[44] E. Sieniawska, T. Baj, Tannins. In Pharmacognosy, 2017, pp 199-232.

[45] S.D. Ali, H.E. Haroun, and A.E. Musa. Haraz bark powder extracts for manufacture of Nappa upper leather as alternatives retanning agents. Journal of Forest Production and Industries, 2(5), 2013, pp 25-29.

[46] G. Grasser, Synthetic Tannins. F. G. A. Enna. (Trans), 13, 1992, ISBN 9781406773019

[47] F.O. Flaherty, W. Roddy, and R.M. Lollar, The chemistry and technology of leather. Robbert E.Krieger Publishing CompNY Malabar, Florida.1978, pp 387-458. 
Karanam Sai Bhavya, Raji P, Jenifer Selvarani A, Antony V Samrot,

Pazhayakath Thevarkattil Mohamed Javad, Appalaraju, V.V.S.S

[48] P.W. Hartzfeld, R. Forkner, M.D. Hunter, and A.E. Hagerman, Determination of hydrolyzable tannins (gallotannins and ellagitannins) after reaction with potassium iodate. Journal of Agricultural and Food Chemistry, 50(7), 2002, pp 1785-1790.

[49] P. Frutos, G. Hervas, G., F.J. Giraldez and A.R. Matelon, Tanning and ruminant nutrition. Spanish Journal of Agricultural Research, 2, 2004, pp 191-202.

[50] O. Koloka, J.C. and Moreki, J. C. Tanning hides and skins using vegetable tanning agents in Hukuntsi sub-district, Botswana. Journal of Agricultural Technology.7 (4), 2011, pp 915-922.

[51] N. Ork, O. Huja, H. Mehemet, and O. Ziymet, Comparative determination of physical and fastness properties of garment leathers tanned with various tanning materials for the leather skirt production. Tekstil ve Konfeksiyon, 24(4), 2014, pp 413-418.

[52] S. H. I. Bi, Combination Tanning Method by Vegetable Tannin-Aldehyde Compound ( I): Combination Tanning by Vegetable Tannin-modified Glutaraldehyde. J.China Leather, 17, 2006.

[53] L. Faxing, L. Yang, and H. Youjie, Preparation and the Properties of Vegetable Extract Used in Low Temperature Tanning. Journal of Leather Science and Engineering 15(1), 2005, pp 2226.

[54] F. Nazir, The profile of vegetable tannins: properties and performance, Leather International, 2011.

[55] C.M. Spencer, Y. Cai, R. Martin, S.H. Gaffney, P.N. Goulding, D. Magnolato, T.H. Lilley, and E. Haslam, Polyphenol complexation - some thoughts and observations.Phytochemistry, 27 (8), 1988, pp 2397-2409.

[56] S.M. Mavlyanov, S.Y. Islambekov, A.I. Ismailov, D.N. Dalimov, N.G. Abdulladzhanova, Vegetable tanning agents. Chemistry of natural compounds,37(1), 2001, pp 1-24.

[57] D.C. Kaith, Informal technical report on forestry of tannin bearing tree crops. Rome: FAO, 1968.

[58] A.N. Kuria, Evaluation of tanning strength and quality of leathers produced by selected vegetable tanning materials from laikipia county, Degree of Master of Science in Leather Science, University of Nairobi, Kenya, 2015.

[59] F. Haojun, S. Bi, L. Shifang, and D. Zhenji, Nanocomposite of protein-silica (titanium) organic-inorganichybrid-a novel concept of leather making. China Leather, 1, 2002.

[60] Y. Lu, Y. Chen, H. Fan, B. Peng, and B. Shi, A Novel Nano-SiO2 Tannage for Making Chrome-Free Leather, 2013.

[61] X.F. Zhang, Z.G. Liu, W. Shen, and S. Gurunathan, Silver nanoparticles: synthesis, characterization, properties, applications, and therapeutic approaches. International journal of molecular sciences, 17 (9), 2016, 1534.

[62] K. Renugadevi, V. Aswini, P. Raji, Microwave irradiation assisted synthesis of silver nanoparticle using leaf extract of Baliospermum montanum and evaluation of its antimicrobial, anticancer potential activity. Asian J. Pharm. Clin. Res, 5(4), 2012, pp 283-287.

[63] A.V. Samrot, P. Raji, A.J. Selvarani, and P. Nishanthini, Antibacterial activity of some edible fruits and its green synthesized silver nanoparticles against uropathogen-Pseudomonas aeruginosa SU 18, Biocatalysis and agricultural biotechnology, 16,2018, pp 253-270.

[64] P. Raji, A.V. Samrot, K.S. Bhavya, M. Sharan, S. Priya, and P. Paulraj, Greener Approach for Leather Tanning Using Less Chrome with Plant Tannins and Tannins Mediated Nanoparticles, Journal of Cluster Science, https://doi.org/10.1007/s10876-019-01597-6. 
[65] P. Thanikaivelan, J.R. Rao, B.U. Nair, and T. Ramasami, Progress and recent trends in biotechnological methods for leather processing. TRENDS in Biotechnology, 22 (4), 2004, pp 181-188.

[66] H.P. Germann, The ecology of leather production - present state and development trends. In Science and Technology for Leather into the Next Millennium (Bailey, D.G. et al., eds, McGrawHill, 1999), pp 283.

[67] J.R. Rao, and T. Ramasami, Waste management in leather processing: a case of chromium. In International Conference on Industrial Pollution and Control Technologies, Hyderabad, Allied Publishers, 1997.

[68] T. Ramasami, and B.G.S. Prasad, Environmental aspects of leather processing. In Proceedings of the 25th Leather Exposition (Dasgupta, S., ed.), Indian Leather Technologists' Association, India, 1991, pp 43-71,

[69] T. Ramasami, K.J. Sreeram, R. Gayatri, Emerging leather processing strategies for waste minimization. In Background Information and Cleaner Technologies in Raw Material Preservation and in the Beamhouse Processes (Buljan, J., ed.), 1998, pp 183-197.

[70] J.R. Rao, B.U. Nair, T. Ramasami, Isolation and characterization of low affinity chromium (III) complex in chrome tanning solutions. J. Soc. Leather Technol. Chem. 81, 1997, pp 234238.

[71] J. Kanagaraj, K.C. Velappan, N.K. Babu, and S. Sadulla, Solid wastes generation in the leather industry and its utilization for cleaner environment, ChemInform 37(49), 2006.

[72] H. Ozgunay, S. Colak, M.M. Mutlu, F. Akyuz, Characterization of Leather Industry Wastes. Polish Journal of Environmental Studies, 16(6), 2007.

[73] S. E. L. I. M. E. Colak, G. Ö. K. H. A. N. Zengin, H. Ozgunay, H. Sarikahya, O. Sari, and L. Yuceer, Utilization of leather industry prefleshings in biodiesel production. Journal of the American Leather Chemists Association, 100(4), 2005, pp 137-141.

[74] I.C. Kantarli, and J. Yanik, Activated carbon from leather shaving wastes and its application in removal of toxic materials. Journal of hazardous materials, 179(1-3), 2010, pp 348-356.

[75] L.C.A. Oliveira, M.C. Guerreiro, M. Gonçalves, D.Q.L. Oliveira, L.C.M. Costa, Preparation of activated carbon from leather waste: A new material containing small particle of chromium oxide. Materials Letters, 62(21-22), 2008, pp 3710-3712

[76] J. Hu, Z. Xiao, R. Zhou, W. Deng, M. Wang, and S. Ma, Ecological utilization of leather tannery waste with circular economy model. Journal of Cleaner Production, 19(2-3), 2011, pp 221-228.

[77] L.F. Cabeza, M.M. Taylor, G.L. DiMaio, E.M. Brown, W.N. Marmer, R. Carrio, P.J. Celma, and J. Cot, Processing of leather waste: pilot scale studies on chrome shavings. Isolation of potentially valuable protein products and chromium. Waste management, 18(3), 1998, pp 211218.

[78] E.J. Jeon, S.J. Bae, D.H. Lee, D.C. Seo, S.K. Chun, N.H. Lee, and J.Y. Kim, Methane generation potential and biodegradability of MSW components, Proc. $11^{\text {th }}$ In Sardinia eleventh international waste management and landfill symposium, Cagliari, Italy, 2007.

[79] M. Catalina, J. Cot, A.M. Balu, J.C. Serrano-Ruiz, R. Luque, Tailor-made biopolymers from leather waste valorisation. Green Chemistry, 14(2), 2012, pp 308-312. 